\title{
A Re-Evaluation of the Choice of an Inflation Target in the Wake of the Global Financial Crisis
}

by

Richard T Froyen ${ }^{1}$

Department of Economics

University of North Carolina

Chapel Hill, NC, USA

\author{
Alfred V Guender ${ }^{2}$ \\ Dept. of Economics and Finance \\ University of Canterbury \\ Christchurch, New Zealand
}

\section{JEL Code: E3, E5, F3}

Key Words: CPI, REX, Domestic Inflation Targets, Broad vs. Narrow Mandate Abstract:

Through an appropriate choice of inflation objective - a real-exchange-rate-adjusted (REX) inflation target - the central bank can limit fluctuations in real economic activity which have become a cause of great concern in recent years in many small open economies. REX inflation targeting dominates CPI targeting from the standpoint of output gap stabilization. CPI inflation targeting dominates REX inflation targeting from the standpoint of stabilizing inflation, nominal interest rates and real exchange rates. These results help inform ongoing discussions of possible alternatives for the existing flexible inflation targeting framework.

Authors' Addresses: ${ }^{1}$ CB\#3305, University of North Carolina at Chapel Hill, Chapel Hill, NC 27599-3305; froyen@email.unc.edu.

${ }^{2}$ Corresponding Author; Private Bag 4800, University of Canterbury, Christchurch, 8140; Alfred.Guender@canterbury.ac.nz.

We thank a referee and the associate editor for helpful comments on earlier drafts of the paper. 
The past is a foreign country. Even the recent past is a foreign country. That is certainly true of the views of leading policymakers.The crisis that broke upon the world in August 2007and then morphed into a widening economic malaise in the high income countries and huge turmoil in the Eurozone, has put not just these countries but the world into a state previously unimagined even by intelligent and well-informed policymakers [Martin Wolf (2014)].

The Global Financial Crisis led to re-appraisals of monetary policy strategies in many countries including New Zealand, Australia, Canada, Sweden, Norway and the United States. One aspect of these re-appraisals is the proper scope of a central bank's mandate. Since the crisis central banks around the world have manifested a heightened sense of urgency for stabilizing the real economy. ${ }^{1}$ Accompanying this development is a growing unease about the appropriateness of inflation targeting as currently practiced. ${ }^{2}$ Most central banks target the CPI inflation rate in the belief that doing so constitutes "best practice" policy. ${ }^{3}$ Is this belief robust to a change in the emphasis toward output stability?

Moreover, the crisis has underscored that a narrow focus on price stability does not guarantee financial stability. Indeed, Mishkin (2017, p.256) argues "price and output stability do not ensure financial stability." A broad consensus has, however, emerged that financial stability is essential for macroeconomic stability. ${ }^{4}$ As a result, financial stability considerations now figure prominently in central bank communications and policy discussions. In small open economies where domestic firms do not adequately hedge their foreign exchange exposure, large exchange rate movements can seriously undermine the stability of the domestic financial sector. ${ }^{5}$ Recognizing this potential threat, Blanchard et al.

\footnotetext{
${ }^{1}$ An amendment to the Reserve Bank Act in New Zealand in 2019, for example, added the goal of "supporting maximum sustainable employment" to its Policy Targets Agreement. For discussion of background to this change, see Orr (2019) and McDermott and Williams (2018).

2 The relevance and suitability of CPI inflation targeting as a monetary policy strategy since the Global Financial Crisis is discussed in Is Inflation Targeting Dead? (2013). Various aspects of this issue with relevance to small open economies are discussed in Central Bank Frameworks: Evolution or Revolution? [Simon and Sutton (2018)].

${ }^{3}$ Svensson (2011) and Henderson and Faust (2004) discuss best-practice aspects of inflation targeting. The preference for a headline CPI target is not universal. The U.S. Federal Reserve targets the core personal consumption deflator.

${ }^{4}$ The Reserve Bank of Australia, whose monetary policy "Statement" recognized a dual mandate even before the financial crisis, included an "articulation of the financial stability objective" after the crisis [Debelle (2018; p.55)].

${ }^{5}$ Mishkin (1999) emphasizes this point in the context of the Asian Financial Crisis. The lack of adequate hedging also became a problem in non-Euro member countries (or associate members) of the European Union during the Global Financial Crisis and the period thereafter. Domestic residents in these countries had borrowed extensively in Euros (or Swiss Francs) in the firm belief that the domestic currency peg (or stable exchange rate)
} 
(2010) call for the mandate of central banks in small open economies to be expanded to include exchange rate stability as a policy goal. ${ }^{6,7}$

In the aftermath of the Global Financial Crisis, central bankers in small open economies have had to operate in a more uncertain world environment. The major world economies are no longer in the stable period from the mid-1980s to 2007 that was termed the "Great Moderation". The financial sectors of these economies are no longer in what Gorton (2012) called the "Quiet Period." Small open economies are particularly vulnerable in this new macroeconomic environment. In the post-crisis period, their financial sectors have had to withstand a series of de-stabilizing shocks such as huge capital inflows and sudden stops caused by shifts in expectations about monetary policy in the United States and elsewhere, terms of trade shocks, and the break-up of goodwill in international trade relations. ${ }^{8}$ These massive disruptions have contributed to further undesirable increases in the volatility of exchange rates, which are a non-negligible source of instability in financial markets as pointed out above.

This paper does not attempt a general re-evaluation of monetary policy strategies in the light of the Global Financial Crisis. Our focus is limited to two related issues both of which centre on the central bank's mandate. The first issue is the relationship between the choice of an inflation objective and the relative emphasis on inflation versus real output in a small open economy model. We compare and contrast an alternative open-economy inflation objective, real-exchange-rate adjusted (REX) inflation, with a standard CPI inflation objective. Initially, the stabilization performance of each inflation targeting strategy is evaluated under a traditional narrow mandate of inflation and output gap stabilization consistent with the Jackson Hole consensus. Next, and this brings us to the second issue, we consider a broader mandate which adds stability of the real exchange rate as a secondary goal for an optimizing central bank. How does this move to a broad mandate affect the relative

\footnotetext{
would be maintained. This proved fallacious. Foreign currency loans to households and non-financial corporations ranged from more than 80 percent of total loans outstanding in Latvia to about 30 percent in Poland (Financial Stability Review, ECB (2010)).

${ }^{6}$ Smets (2014) reviews the debate on the scope of a central bank's mandate in a closed-economy context. A broader mandate for a central bank is proposed by advocates of both the "Leaning against the Wind" view Woodford (2012) and "Financial Stability is Price Stability view [Brunnermeier and Sannikov (2014)].

${ }^{7}$ Exchange rate stability is, of course, only one aspect of financial stability. We return to this issue in Section 2.

${ }^{8}$ See Pereira da Silva (2015) for an account of how both advanced and emerging countries have coped with the massive shifts in capital flows that have been triggered by unconventional policy measures in the United States, Europe, and Japan. A few advanced small open economies such as Australia and New Zealand were less affected by these policy developments abroad. In New Zealand, however, RBNZ repeatedly voiced its concern in 2014 about the unsustainable und unjustifiably high NZ dollar-US dollar exchange rate.
} 
desirability of alternative inflation targets? ${ }^{9}$ What is the nexus between an increased emphasis on output stability and on financial stability, represented by real exchange rate stability, in determining the optimal flexible inflation targeting strategy?

To address these issues we employ a small New Keynesian open economy model. We evaluate optimal policy under Woodford's timeless perspective for a CPI and alternatively for a REX inflation target. ${ }^{10}$ The implications for macroeconomic stability of following each strategy are then analysed for different weights on inflation and output in the central bank loss function. Both a narrow mandate (traditional dual mandate) and a broad mandate (stability of the real exchange rate is an additional but secondary goal) are considered.

The findings of this paper suggest that a REX inflation objective is the preferred choice for a central bank that values real output stability and is vested with a narrow mandate. Once stability of the real exchange rate becomes of some concern to the central bank the inherent advantage of a REX-inflation targeting strategy in stabilizing output diminishes though a sharp contrast still exists with CPI inflation targeting in terms of output versus inflation stabilization. The role that greater instability in the external environment plays in the choice of an inflation objective is shown also to be sensitive to the mandate of the central bank.

\section{A Monetary Policy Framework for a Small Open Economy}

Our analysis is carried out in a policy framework that consists of a small openeconomy model, a central bank loss function as well as alternative target rules for optimal policy under the timeless perspective. The model and loss function are described in this section. The derivation of the target rules is carried out in section 3 .

\subsection{A Small Open Economy Model}

The model employed for our evaluation of alternative inflation targeting strategies is a relatively standard New Keynesian open-economy model. One distinctive feature of the model is an open-economy Phillips Curve with a direct real exchange rate channel that stems from pressures on domestic firms from competitors in international markets.

\footnotetext{
${ }^{9}$ In previous work Froyen and Guender (2017) evaluate the performance of CPI, domestic and REX inflation targeting under optimal discretionary policy. They don't distinguish between a broad and a narrow central bank mandate. Froyen and Guender (2018) compare optimal policy under the timeless perspective with Taylor rules for both types of mandate. They consider only CPI and domestic inflation targeting.

${ }^{10}$ We also consider a domestic inflation target. Results with this specification are discussed at a later point.
} 
This specification of the Phillips Curve (equation 1) is an extension of the Rotemberg (1982) quadratic cost adjustment model of monopolistically competitive firms. In our openeconomy version, in addition to menu costs and a mark-up on benchmark prices of domestic competitors, firms take into consideration competitiveness abroad. Thus, they respond to exchange rate-induced changes in the terms of trade. ${ }^{11}$

Equation (2) is an open-economy IS relation with a real interest rate and a real exchange rate channel. A foreign output shock and an idiosyncratic shock also affect the demand for domestic output. The derivation of this form of the forward-looking IS relation is explained in Guender (2006).

Equation (3) is the linearized uncovered interest rate parity condition; apart from a stochastic risk premium $\left(\varepsilon_{\mathrm{t}}\right)$, agents are assumed to trade in a frictionless international bond market. Equation (4) sets out the relationship between CPI inflation and the real exchange rate under perfect exchange rate pass-through (4). ${ }^{12}$

$$
\begin{aligned}
& \pi_{t}=\beta E_{t} \pi_{t+1}+\kappa y_{t}+b\left(q_{t}-q_{t-1}\right)-\beta b\left(E_{t} q_{t+1}-q_{t}\right)+u_{t} \\
& y_{t}=E_{t} y_{t+1}-a_{1}\left(R_{t}-E_{t} \pi_{t+1}^{C P I}\right)+a_{2}\left(q_{t}-E_{t} q_{t+1}\right)+a_{3}\left(y_{t}^{f}-E_{t} y_{t+1}^{f}\right)+v_{t} \\
& R_{t}-E_{t} \pi_{t+1}=R_{t}^{f}-E_{t} \pi_{t+1}^{f}+E_{t} q_{t+1}-q_{t}+\varepsilon_{t} \\
& \quad \pi_{t}^{C P I}=\pi_{t}+\gamma \Delta q_{t}
\end{aligned}
$$

where

$\pi_{t}=$ the rate of domestic inflation, $E_{t} \pi_{t+1}^{C P I}=$ the expected rate of CPI inflation, $q_{t}=$ the real exchange rate (with an increase in $q_{t}$ implying a real depreciation of the domestic currency), $y_{t}$ $=$ the output gap, $R_{t}=$ the nominal rate of interest (policy instrument), $R_{t}^{f}=$ the foreign nominal rate of interest, $E_{t} \pi_{t+1}^{f}=$ the expected foreign rate of inflation, $y_{t}^{f}=$ the foreign output gap. Lower case variables represent logarithms. All parameters are positive. The discount factor $\beta$ is less than or equal to one.

We do not estimate the model. The model is calibrated using values taken from previous studies of small open economies.

\footnotetext{
${ }^{11}$ Support for this responsiveness in provided by survey evidence for the United Kingdom in Greenslade and Parker (2012) and for New Zealand in Parker (2017). Additional support for the influence of exchange rate changes on price setting in the United Kingdom is provided by Bunn and Ellis (2012a, 2012b). For the derivation of the open-economy Phillips Curve see Froyen and Guender (2017).

12 In equation (4) $y$ is the degree openness of the economy. Assuming uncovered interest rate parity and perfect exchange rate pass-through help simplify the analysis.
} 


\subsection{The Choice of a Central Bank Loss Function}

The exercise we carry out is to evaluate the desirability of alternative flexible inflation targeting strategies for variations in the central bank loss function. The underlying reasons for changes in the loss function are motivated in the introduction. Before going into detail about our choice of a loss function, consider an example of motivation behind the change in one central bank's framework. As noted in the introduction, in 2019 the Reserve Bank of New Zealand added an explicit target of "supporting maximum sustainable employment." Reserve Bank Governor Adrian Orr described the change in the Reserve Bank's mandate as a response to an "evolving social contract" in a "national and cultural context.' - a context where the "dynamics of global and national economies are interacting to a greater extent and, at times, working at cross purposes."

\subsubsection{The General Issue}

The optimal monetary policy literature distinguishes two approaches to the choice of the loss function for the central bank. One emphasizes a welfare-theoretic approach; the central bank minimizes a loss function given by an approximation to a representative household's utility function while the other is a "simple representation of conventional central bank objectives [Woodford (2011, p.728)].” The welfare theoretic approach has a strong claim in micro-based models. The approach also has its critics, e.g., Blanchard (2016), Sims (2012), Clarida, Gali and Gertler (1999), to name but a few. We take no position on the general issue of which approach is preferable. We agree with Blanchard (2016) that one should take a pluralistic approach concerning the choice. To represent changes due to the broad type of forces such as Governor Orr describes, we adopt the simple representation of objectives.

\subsubsection{The Role of the Exchange Rate}

There remains the question of what should be the central bank's objectives? We consider the traditional dual mandate: an inflation target and the output gap, as well as a broader mandate that includes stability of the real exchange rate.

In the introduction we motivate concern for real exchange rate stability as an element in growing concern for financial stability. Kaefer (2014) lists as financial stability objectives: exchange rates, asset prices, leverage and interest rate spreads. In addition to being one of these objectives exchange rate stability is interconnected with the others. 
Blanchard et.al. (2010) argue that "[L]arge fluctuations in exchange rates, due to shifts in capital flows (as we saw during the crisis) or other factors, create large disruptions in activity... when a significant portion of domestic contracts is denominated in foreign currency (or is somehow linked to its movements), sharp depreciations can cause severe balance sheet effects with negative consequences for financial stability, and thus, output.” Kaefer (2014) makes a similar point and adds that "Capital inflows trigger credit and asset bubbles, which in turn generate the danger of a subsequent collapse (p. 166)." Rey (2016) emphasizes the existence of an international credit or risk-taking channel of monetary policy that works through the effects of changes in US monetary policy on exchange rates which in turn affect the net worth of domestic banks, and as pointed out in the introduction, the net worth of firms, and households. Domestic financial stability and economic activity clearly depend on the financial health of all three entities. Gourinchas and Obstfeld (2012) argue that a sharp real appreciation of the currency alongside increases in leverage is arguably a reliable indicator of financial instability.

Our choice to include exchange rate stability as a secondary stabilization objective accords with Smets' (2014) view that price and output stability dominate financial stability as final objectives. In the literatures he reviews, Kaefer (2014, p.167) finds support for the view that "the weight given to that exchange rate should be considerably smaller than that given to inflation and output". ${ }^{13,14}$

\section{Alternative Flexible Inflation Targeting Strategies}

This section presents a brief analysis of the way central banks choose optimal policy under the alternative targeting strategies. We begin with a discussion of REX inflation targeting and then proceed to a discussion of CPI inflation targeting.

3.1 Targeting "R(eal)-EX(change)-Rate-Adjusted” Inflation under Optimal Policy from a Timeless Perspective.

\footnotetext{
${ }^{13}$ Ratcliffe and Kendall (2019) list "unnecessary instability" in interest rates or the exchange rate as among secondary policy objectives for the Reserve Bank of New Zealand.

${ }^{14}$ There are additional rationales for inclusion of exchange rate stability in the central bank objective function. Blanchard et al. (2010) argue that appreciations in the real exchange rate "squeeze the tradeable sector." This point was echoed by the Brazilian Finance Minister Mantaga "We're in the midst of a currency war... This threatens us because it takes away our competitiveness." Aizenman et.al. (2017) motivate exchange rate volatility in the central bank objective function via an effect on potential output. DePaoli (2009), within a framework with a utility-based loss function, motivates a role for the real exchange rate via a terms of trade externality. Within this framework, real exchange rate volatility may be either too low or high for optimality under the standard dual mandate (output and domestic inflation).
} 
REX inflation is defined as domestic inflation stripped of the effects of changes in the real exchange rate. Defining the inflation objective in this way transforms an open-economy Phillips curve into a closed-economy version. As a result, the exchange rate channel is effectively shut down and, abstracting from the expectations channel, the monetary policy transmission mechanism works solely through the output gap. A central bank targeting REX inflation in an open economy is thus in a position to stabilise perfectly the output gap against all demand-side disturbances, in exactly the same fashion as a central bank targeting inflation in the canonical closed-economy New Keynesian model can neutralize an aggregate demand shock. In case of an aggregate demand disturbance in the open economy, the central bank merely needs to determine the appropriate setting for the nominal interest rate that perfectly stabilizes the output gap and satisfies the UIP condition.

The REX inflation concept is related to Laurence Ball's real-exchange-rate-adjusted measure in a backward-looking New Keynesian framework. ${ }^{15}$ Both measures are meant to represent core inflation objectives in open economies.

Defining

$\pi_{t}^{R E X}=\pi_{t}-b\left(q_{t}-q_{t-1}\right)$

as the rate of domestic inflation purged of the real exchange rate effect allows us to rewrite the original open-economy Phillips curve as

$\pi_{t}^{R E X}=\beta E_{t} \pi_{t+1}^{R E X}+\kappa y_{t}+u_{t}$

Written in this form, equation (6) looks like a closed-economy Phillips curve except for the definition of the rate of inflation.

Under a REX inflation targeting strategy (and a zero inflation target), the central bank solves the following optimization problem:

$$
\begin{gathered}
\min _{\pi_{t}^{R E X}, y_{t}, q_{t}} E_{t} \sum_{i=0}^{\infty} \beta^{i}\left[y_{t+i}^{2}+\mu \pi_{t+i}^{R E X^{2}}+\delta q_{t+i}^{2}\right] \\
\pi_{t}^{R E X}=\beta E_{t} \pi_{t+1}^{R E X}+\kappa y_{t}+u_{t} \\
\text { and } \\
y_{t}=E_{t} y_{t+1}-a_{1}\left(R_{t}^{f}-E_{t} \pi_{t+1}^{f}+\varepsilon_{t}\right)-\left(a_{1}(1-\gamma)+a_{2}\right)\left(E_{t} q_{t+1}-q_{t}\right)+a_{3}\left(y_{t}^{f}-E_{t} y_{t+1}^{f}\right)+v_{t}
\end{gathered}
$$

\footnotetext{
${ }^{15}$ Ball (1999) calls his real-exchange-rate-adjusted measure "long-run inflation." It is defined as overall (domestic and imported) inflation purged of the effect of the lag (not the change) of the real exchange rate.
} 
The specification of the objective function of the central bank permits consideration of two scenarios under optimal policy from a timeless perspective. The first scenario describes a situation where the central bank has a broad mandate and is charged with pursuing price, output gap, and real exchange rate stability $(\mu, \delta>0)$. The second scenario describes the case of a narrow or classic dual mandate where $\mu>0$ but $\delta=0$.

Solving the optimization problem yields the target rule under REX inflation targeting:

$$
\frac{\delta \Delta q_{t}}{a_{1}(1-\gamma)+a_{2}}+\Delta y_{t}+\mu \kappa \pi_{t}^{R E X}=0
$$

Under a broad mandate where real exchange rate stability matters, the central bank trades off changes in real output for changes in the real exchange rate and the REX inflation rate (changes in the REX price level). Notice that this trade-off depends on demand-side parameters ( $a_{1}$ and $a_{2}$ ), the degree of openness $(\gamma)$, and the emphasis on real exchange rate stability $(\delta)$ in addition to the standard parameters $\mu$ and $\kappa .{ }^{16}$ The former parameters determine the relative importance of the real exchange rate in the target rule and hence its stability overall. If the central bank has a narrow dual mandate, then $\delta=0$ and the target rule reduces to an expression similar to the canonical closed-economy target rule:

$$
\Delta y_{t}+\mu \kappa \pi_{t}^{R E X}=0
$$

In this case the central bank trades off changes in real output for changes in the level of the real-exchange-rate-price level (REX inflation rate) only. The implementation of optimal policy has no regard for instability of "rates" other than the REX inflation rate.

3.2 Targeting the Rate of CPI Inflation under Optimal Policy from a Timeless Perspective

If the focus of the central bank rests on the CPI inflation rate, then it minimizes

$$
E_{t}\left[\sum_{i=0}^{\infty} \beta^{i}\left[y_{t+i}^{2}+\mu \pi_{t+i}^{C P I 2}+\delta q_{t+i}^{2}\right]\right]
$$

subject to the constraint which is represented by the model economy. After rewriting the structure of the economy in terms of the CPI inflation rate, we can restate the policy objective as:

$$
\min _{y_{t}, \pi_{t}^{C P}, q_{t}} E_{t}\left[\sum_{i=0}^{\infty} \beta^{i}\left[y_{t+i}^{2}+\mu \pi_{t+i}^{C P I 2}+\delta q_{t+i}^{2}\right]\right]
$$

s. t.

\footnotetext{
${ }^{16}$ Both $a_{1}$ and $a_{2}$ depend on the degree of openness $\psi$. See Guender (2006) or Svensson (2000).
} 
$\pi_{t}^{C P I}=\beta E_{t} \pi_{t+1}^{C P I}+\kappa y_{t}+(1+\beta)(\gamma+b) q_{t}-(\gamma+b) q_{t-1}-\beta(\gamma+b) E_{t} q_{t+1}+u_{t}$

and

$y_{t}=E_{t} y_{t+1}-a_{1}\left(R_{t}^{f}-E_{t} \pi_{t+1}^{f}+\varepsilon_{t}\right)-\left(a_{1}(1-\gamma)+a_{2}\right)\left(E_{t} q_{t+1}-q_{t}\right)+a_{3}\left(y_{t}^{f}-E_{t} y_{t+1}^{f}\right)+v_{t}$

The target rule for a CPI inflation targeting strategy under optimal policy proves complex, defies easy interpretation, and is therefore not reported. ${ }^{17}$

The variances of the endogenous variables under both targeting strategies are determined by numerical solution and reported in the next section.

4. REX vs. CPI Inflation Targeting under a Narrow and Broad Mandate

In this section we evaluate the performance of CPI versus REX inflation targeting for different weights on the policy objectives, different mandates for the central bank and in alternative macroeconomic environments. The metric we use is the variance of the macroeconomic variables in our small open economy model for each configuration. We also compute a loss score which is the value of the loss functions in section three for each flexible inflation targeting strategy. The parameters used in these calculations as well as the assumptions made about stochastic terms in the model are given in a footnote to Table 1.

As a point of departure, let us consider first what we regard as a conventional view of inflation targeting prior to the Global Financial Crisis. A central bank chooses (or is delegated) a measure of inflation as its price stability objective and stabilizes the level of real output around its full-employment level. The overriding objective of the central bank is to ensure price stability with some concern given to keeping output fluctuations in check, a strategy commonly referred to as flexible inflation targeting. Columns 1 and 2 of Table 1 present the outcomes of two embodiments of flexible inflation targeting, one centred on the rate of CPI inflation and the other on REX inflation. (We return to columns 3 and 4 in section 4.3.) We represent the strong emphasis on stabilizing the rate of inflation by choosing a value $(\mu=8)$ in the loss function. Given this strong emphasis on price stability, the central bank is

\footnotetext{
${ }^{17}$ A straightforward Interpretation of the CPI inflation target rule is made impossible by the presence of undetermined coefficients. These coefficients are instrumental in determining the effect of the state variable, the lagged real exchange rate, on the forward-looking expectations of the three choice variables. In addition, the weights on the target variables cannot be signed unambiguously in all cases. One clear result that emerges is that history-dependence matters more compared to REX inflation targeting as do parameters that characterize the demand-side of the economy.
} 
far more likely to choose the CPI inflation rate as its preferred inflation objective. A CPI inflation objective makes for greater stability of both rates of inflation (particularly CPI inflation at 0.04 ), the real exchange rate, and the policy instrument. The only advantage of REX inflation targeting is its superior ability to stabilize the output gap.

As explained in the introduction, in the wake of the worst financial crisis since the Great Depression, the narrow focus on price stability as a final objective is no longer taken for granted. Two planks of the pre-crisis view have been challenged. First, critics have argued that central banks' overriding concern with price stability is not sufficient for maintaining financial stability. In a small open economy the real exchange rate is a barometer of the health of the domestic financial sector and the competitiveness of the domestic economy on the world stage. As such the real exchange rate should be a secondary final objective in an expanded inflation targeting strategy. Second, the emphasis on keeping inflation low and stable relative to the output gap should be reconsidered.

The reconsideration of inflation targeting frameworks raises an important question. Would a central bank that takes both points of criticism seriously reverse its decision to choose the rate of CPI inflation as its inflation objective? To answer this question, we make two changes to the existing framework. First, the relative weight on inflation variability is reduced from $\mu=8$ to $\mu=1$ for both CPI and REX inflation targeting strategies. Second, we distinguish between a narrow and a broad central bank mandate.

For equal weights on the rate of inflation and the output gap in the objective function, the variances of the endogenous variables under optimal policy for CPI and REX inflation targeting strategies appear in Table 2. The results for both strategies are arranged according to mandate and examined in subsections 4.1 and 4.2.

\subsection{A Narrow Mandate}

Columns 1 and 3 of Table 2 show the variances of the five variables for a REX and CPI inflation target, respectively, under a narrow mandate. A stark contrast emerges between REX inflation and CPI inflation targeting with the former strategy keeping fluctuations in the output gap to a bare minimum (0.04) while the latter strategy provides greater stability of all "rates". 18

\footnotetext{
${ }^{18}$ This assessment of course rests to some extent on the specific values chosen for the parameters of the model and the variances of the shocks. In their study of the performance of inflation targeting strategies, Froyen and Guender (2017) carry out multiple robustness checks without overturning any of their reported findings. In section 4.3 we report further on the robustness issue.
} 
Under a REX inflation target, stabilizing the output gap also stabilizes REX inflation to a degree as the real exchange rate channel in the Phillips curve is not operative. Thus, when vested with a narrow mandate, the central bank simply does what it takes to shield output from demand-side disturbances without worrying about the consequences for the variability of the policy instrument and the real exchange rate. Operationally, this implies that the central bank adjusts the policy instrument so that in equation (9) the output gap does not change, requiring no compensating change in REX inflation. In contrast, under a CPI inflation target, the central bank cannot afford to use the policy instrument as aggressively, as doing so would cause large changes in the real exchange rate that in turn would destabilize the CPI inflation rate (as happens with REX inflation targeting). As the central bank uses the policy instrument more cautiously under CPI inflation targeting, it does not reverse the effects of demand-side shocks on output to the same extent as under REX inflation targeting. This advantage of REX inflation targeting over CPI inflation targeting in stabilizing the output gap is borne out by the entries in the first row of Table 2. The variance of the output gap under a CPI target is almost 16 times the size of same under a REX inflation target. A central bank that values relative output stability $(\mu=1)$ under a dual mandate has a far greater incentive to choose a REX inflation target than a central bank with an overarching concern for relative price stability $(\mu$ $=8)$.

\subsection{A Broad Mandate}

Once the central bank puts even a modest weight on exchange rate stability, adjustment of the policy instrument with a consequent effect on the real exchange rate is no longer costless under a REX inflation target. Therefore, the central bank uses the policy instrument less aggressively; the variability of the nominal interest rate falls by 60 percent. This has costs as well as benefits. For a REX inflation target (entries in column 2), the cost is that demand-side disturbances now affect the output gap and hence flow through to REX inflation. There is a seven-fold increase in the variance of the output gap from 0.04 to 0.29. The benefit is that the variance of the real exchange rate falls to about a third of its value under the narrow mandate. The broader mandate also helps bring down the variance of CPI inflation by nearly 50 percent.

Column 4 describes what happens to the variability of the key variables under a CPI inflation target as the central bank's mandate broadens. Adopting a broader mandate leads to relatively moderate increases or decreases in the variability of all variables except for the real exchange rate and CPI inflation. With a broader mandate, a CPI inflation targeting strategy 
becomes even more restrained. The central bank exercises greater caution in using its policy instrument so as to reduce the variance of the real exchange rate further (by nearly 50 percent). Targeted CPI inflation is unchanged.

A sharp contrast still remains between CPI and REX inflation targeting under a broad mandate. Under CPI inflation targeting the variance of CPI inflation is less than half the value under REX inflation targeting while the variance of the output gap is more than twice as high. ${ }^{19}$

\subsection{Changing the Macroeconomic Environment: Greater Aggregate Demand Uncertainty}

One important issue that has not been addressed so far in our analysis concerns the role of macroeconomic shocks in a central bank's choice of an inflation targeting strategy. Michael Woodford, a key figure in the development of inflation targeting, has written that the strategy was "expected to eliminate a particular source of macroeconomic instability, namely, the possibility of wage-price spirals triggered by commodity price shocks of the kind that had been problematic in the 1970s (2012, p.7)." As pointed out in the introduction, in the postfinancial crisis era small open economies are exposed to several other important sources of instability. In this sub-section we assess to what extent differences in the volatility of demandside relative to cost-push shocks affect the performance of targeting strategies in the pre-crisis and post-crisis environment.

There are five different shocks in the model. Four of them are considered to be demand-side disturbances $\left(v, R^{f}, \varepsilon, y^{f}\right)$. We now increase the size of the variances of these shocks from 1 to 4 while leaving the variance of the cost-push shock unchanged. The change is meant to capture the recognition by policymakers in small open economies of greater instability in the world economy. Motivation for a link between this change in the variability of shocks facing policymakers and their choice of an inflation targeting strategy is tied to our earlier observation that REX inflation targeting under a narrow mandate fully stabilizes the output gaps and inflation objective against demand-side shocks while CPI inflation targeting due to the role of the exchange rate in the CPI cannot do so. Greater instability of aggregate demand should thus make ceteris paribus REX inflation targeting a more attractive monetary policy strategy.

\footnotetext{
${ }^{19}$ A third strategy to consider is domestic inflation targeting. Under a narrow mandate, its stabilization performance lies between that of REX and CPI inflation targeting but closer to the former. A broader mandate causes further convergence between the performance of domestic and REX inflation targeting. Domestic inflation targeting is slightly better at stabilizing "rates" while REX inflation targeting retains a modest edge in stabilizing the output gap.
} 
The third and fourth columns of Table 1 show the variances of the variables of the model economy in the pre-crisis state after the four-fold increase in the size of the variances of the demand-side shocks. There is of course no change in REX inflation or output gap variability under REX inflation targeting, but there are substantial costs associated with following this core inflation strategy. These costs fall squarely on the remaining variables of the model. The variances of CPI inflation, the policy instrument, and the real exchange rate shoot up in dramatic fashion. The variances of all variables increase under CPI inflation targeting with output gap variability now being topped only by the variability of the policy instrument. CPI inflation variability, though doubling, remains low

Turning attention to Table 3 which describes the post-crisis scenario and assumes higher volatility of aggregate demand disturbances, we see that a clear pattern emerges in the behaviour of the macroeconomic variables. ${ }^{20}$ Going from left to right, i.e. from a narrow mandate and REX inflation targeting to a broad mandate and CPI inflation targeting strategy, we observe

- a steady and pronounced increase in the variance of the output gap and very little change in the variance of the REX inflation rate.

- steady and pronounced decreases in the variance of the CPI inflation rate, the policy instrument, and the real exchange rate.

REX inflation targeting maintains its superiority over CPI inflation targeting in stabilizing the output gap while CPI inflation targeting continues to dominate from the viewpoint of stabilizing the rate of CPI inflation, the nominal interest rate, and the real exchange rate.

\section{Conclusion}

This paper shows that the behaviour of key macroeconomic variables is heavily influenced by the choice of the inflation targeting strategy, the mandate of the central bank, and its relative concern for price stability. An optimizing central bank with a narrow mandate and equal concern for price and output stability can ensure a relatively high degree of real output stability under REX inflation targeting. A broader mandate erodes the appeal of REX inflation targeting. While CPI inflation targeting cannot match the output-stabilizing record of REX inflation targeting, it is better poised to limit fluctuations in all rates of inflation, the real exchange rate, and the policy instrument. Under a broad mandate and equal concern for price

\footnotetext{
${ }^{20}$ Such a pattern, albeit less clear, is also visible in Table 2.
} 
and output stability, the stark contrast between CPI and REX inflation targeting in stabilizing the output gap and all "rates" diminishes but does not go away.

Carolyn Wilkins, Senior Deputy Governor of the Bank of Canada, stated in a speech entitled "Choosing the Best Monetary Policy Framework for Canada," that "even a wellfunctioning monetary policy framework deserves an open-minded discussion, particularly in the post-crisis world we live in" (Wilkins (2018)). Such a discussion in a CPI inflation targeting country as it confronted the changes discussed here would find forces pushing in opposite directions. Were the only change to be an increased emphasis on output stability, our analysis suggests that a move to REX inflation targeting might be attractive. But given increased concern with financial stability, the advantages of CPI targeting in stabilizing all "rates" is a counterbalancing factor. While the model here has its limitations and we consider only a subset of the relevant issues, the analysis is consistent with the result that many such discussions (including that in Canada) have not resulted in the abandonment of CPI inflation targeting.

\section{References:}

Aizenman, J. Y. Jinjarak, G. Estrada and S. Tian (2017), "Flexibility of Adjustment to Shocks," NBER Working Paper 23467.

Ball, L. (1999). "Policy Rules for Open Economies," In: Taylor J. B. (Ed.): Monetary Policy Rules, The University of Chicago Press, Chicago, 129-156.

Blanchard, O. (2016) "Do DSGE Models Have a Future?" Peterson Institute for International Economics, Washington D.C. PR:16-11.

Blanchard, O., G. Dell'Ariccia, and P. Mauro (2010). "Rethinking Macroeconomic Policy," Journal of Money, Credit and Banking, vol. 42, 199-215.

Brunnermeier, M. and Y. Sannikov (2014). "A Macroeconomic Model with a Financial Sector," American Economic Review vol. 104, 379-421.

Bunn, P. and C. Ellis (2012a). "How Do Individual U.K. Producer Prices Behave?" Economic Journal, vol.122, F16-F34.

Bunn, P and C. Ellis (2012). "Examining the Behavior of Individual U.K. Consumer Prices," Economic Journal, vol 122, F35-F55.

Clarida,R., J. Gali and M. Gertler (1999). "The Science of Monetary Policy: A New Keynesian Perspective,” Journal of Economic Literature, vol. 37, 1661-1707.

Debelle, G. (2018). "Twenty-five Years of Inflation Targeting in Australia," in Simon J. and M. Sutton (eds.) Central Bank Frameworks: Evolution or Revolution? Reserve Bank of Australia..

DePaoli B. (2009). "Monetary Policy and Welfare in a Small Open Economy," Journal of International Economics, vol.77, 11-42. 
European Central Bank (2010). Financial Stability Report, June.

Faust, J. and D. Henderson (2004). "Is Inflation Targeting Best-Practice Monetary Policy?" Federal Reserve Bank of St. Louis Review, July/August, vol. 86 (4), 117-43.

Froyen, R. and A. Guender (2017). "What to Aim for? The Choice of an Inflation Target when Openness Matters," Open Economies Review, vol. 28, 167-190.

Froyen, R. and A. Guender (2018). "The Real Exchange Rate in Open-Economy Taylor Rules: A Re-Assessment," Economic Modelling, vol.73, 140-151.

Gorton, G. (2012). Misunderstanding Financial Crises, New York: Oxford University Press.

Gourinchas, P. and M. Obstfeld (2012). "Stories of the Twentieth Century for the TwentyFirst," American Economic Journal: Macroeconomics, vol. 4, 226-65.

Greendale, J and M. Parker (2012). "New Insight into Price-Setting Behavior in the United Kingdom, Economic Journal, vol. 122, F1-F15.

Guender, A. (2006). "Stabilizing Properties of Discretionary Monetary Policies in a Small Open Economy,” Economic Journal, vol. 116, 309-326.

Is Inflation Targeting Dead? Central Banking after the Crisis. (2013). Edited by Lucrecia Reichlin and Richard Baldwin. https://voxeu.org/sites/default/files/file/P248\%20inflation\%20targeting(2).pdf

Kaefer, B. (2014). "The Taylor Rule and Financial Stability: A Literature Review with Applications to the Eurozone," Review of Economics, vol. 65, 159-192.

McDermott, J. and R. Williams (2018). "Inflation Targeting in New Zealand: An Experience in Evolution," in Simon J. and M. Sutton (eds.), Central Bank Frameworks: Evolution or Revolution? Reserve Bank of Australia.

Mishkin, F.S. (1999). "Lessons from the Asian Crisis," Journal of International Money and Finance, vol. 18, 709-723.

Mishkin, F. S. (2017). "Rethinking Monetary Policy after the Crisis," Journal of International Money and Finance, vol. 73, 252-274.

Orr, A. (2019) “In Service to Society: New Zealand's Revised Monetary Policy Framework and the Imperative for Institutional Change," Speech 29/3.Reserve Bank of New Zealand.

Parker, M. (2017). "Price Setting Behaviour in New Zealand," New Zealand Economic Papers, vol. 51, 217-236.

Pereira da Silva, L.A. (2015). “'Sudden Floods' and Sudden Stops of Capital Flows in an Environment of Ultra-Low Interest Rates: an Equal Opportunity Menace for Emerging and Advanced Economies Alike," Remarks at $51^{\text {st }}$ SEACEN Governors' High Level Seminar, Manila, November $26^{\text {th }}$.

Ratcliffe J. and R. Kendall (2019). “Monetary Policy Strategy in New Zealand, ” Reserve Bank of New Zealand Bulletin, vol. 82, April, 1-25. 
Rey, H. (2016). "International Channels of Transmission of Monetary Policy and the Mundellian Trilemma," NBER Paper 21852.

Sims, C. (2012). "Statistical Modelling of Monetary Policy and its Effects," American Economic Review, vol. 102, 1187-1206.

Simon, J. and M. Sutton (eds.), (2018). “Central Bank Frameworks: Evolution or Revolution?" Reserve Bank of Australia.

Smets, F. (2014). "Financial Stability and Monetary Policy: How Closely Interlinked?" International Journal of Central Banking, vol. 10, 263-300.

Svensson, L. (2000). 'Open Economy Inflation Targeting,' Journal of International Economics, vol. 50, 117-53.

Svensson, L. (2011).” Inflation Targeting,” In Friedman B.M. and M. Woodford: (Eds.): Handbook of Monetary Economics, Vol. 3 Amsterdam" Elsevier 1237-1302.

Wilkins, C.A., (2018). "Choosing the Best Monetary Policy Framework for Canada," Bank of Canada, Speech, November 20.

Wolf, M. (2014).The Shifts and Shocks. London: Penguin.

Woodford, M. (2011).” Optimal Monetary Stabilization Policy" In Friedman B.M. and M. Woodford (Eds.): Handbook on Monetary Policy, Vol. 3 Amsterdam: Elsevier, 723828.

Woodford, M. (2012). "Inflation Targeting and Financial Stability.” Economic Review (Sveriges Riksbank) issue 1, 7-32. 
Table 1: The Performance of Flexible Inflation Targeting (IT) Strategies: Measures of Volatility in the pre-Crisis Situation.

\begin{tabular}{|c|c|c|c|c|}
\hline & $\begin{array}{l}\text { REX-IT } \\
\text { Narrow } \\
\mu=8, \delta=0 \\
\sigma^{2}=1 \text { for } \\
\text { all shocks }\end{array}$ & $\begin{array}{l}\text { CPI-IT } \\
\text { Narrow } \\
\mu=8, \delta=0 \\
\sigma^{2}=1 \text { for } \\
\text { all shocks }\end{array}$ & $\begin{array}{l}\text { REX-IT } \\
\text { Narrow } \\
\mu=8, \delta=0 \\
\sigma^{2}=4 \text { for } \\
\text { demand } \\
\text { shocks }\end{array}$ & $\begin{array}{l}\text { CPI-IT } \\
\text { Narrow } \\
\mu=8, \delta=0 \\
\sigma^{2}=4 \text { for } \\
\text { demand } \\
\text { shocks }\end{array}$ \\
\hline$V(y)$ & 0.85 & 2.03 & 0.85 & 5.09 \\
\hline$V\left(\pi^{R E X}\right)$ & 0.65 & 0.64 & 0.65 & 0.66 \\
\hline$V\left(\pi^{C P I}\right)$ & 1.90 & \begin{tabular}{|l|}
0.04 \\
\end{tabular} & 7.36 & 0.08 \\
\hline$V(R)$ & 5.04 & 2.04 & 20.01 & 7.36 \\
\hline$V(q)$ & 8.97 & 4.16 & 26.01 & 4.92 \\
\hline Loss & 6.08 & 2.38 & 6.08 & 5.75 \\
\hline
\end{tabular}

Notes:

1. Slight differences exist between computed loss scores and individual variances due to rounding error.

2. Demand shocks include all shocks of the model except for the cost-push shock in the Phillips curve.

3. The following parameters are used in calculating the variances of the endogenous variables (based largely on Svensson (2000) and Guender (2006)):

$a_{1}=0.45, a_{2}=0.195, a_{3}=0.27, b=0.1, \kappa=0.1, \beta=1$. All shocks $\left(v_{t}, u_{t}, \varepsilon_{t}, y_{t}^{f}, R_{t}^{f}, \pi_{t}^{f}\right)$ are mean zero disturbances with a standard deviation set at unity unless stated otherwise. All reported variances and loss scores are computed with the help of DYNARE. 
Table 2: The Performance of Alternative Inflation Targeting (IT) Strategies.

\begin{tabular}{|l|l|l|l|l|}
\hline & REX-IT & REX-IT & CPI-IT & CPI-IT \\
Narrow & Broad \\
& $\mu=1, \delta=0$ & $\begin{array}{l}\mu=0.9090 \\
\delta=0.1818\end{array}$ & $\begin{array}{l}\mu=1, \delta=0 \\
\text { Narroad } \\
\mu=0.9090 \\
\delta=0.1818\end{array}$ \\
\hline$V(y)$ & 0.04 & 0.29 & 0.63 & 0.72 \\
\hline$V\left(\pi^{R E X}\right)$ & 0.86 & 0.90 & 0.80 & 0.85 \\
\hline$V\left(\pi^{C P I}\right)$ & 2.55 & 1.35 & 0.62 & 0.62 \\
\hline$V(R)$ & 5.01 & 2.01 & 1.76 & 1.62 \\
\hline$V(q)$ & 5.85 & 1.90 & 2.31 & 1.18 \\
\hline Loss & 0.91 & 1.43 & 1.26 & 1.44 \\
\hline
\end{tabular}

Notes:

1. Hereafter we assume that the policymaker is concerned in equal measure about output gap and inflation variability.

2. Under a broad mandate, real exchange rate stability is a secondary policy goal with its relative weight measuring one fifth the size of the relative weight on inflation stability $(\delta=0.2 \mu)$.

3. To avoid inflating the variances of the variables under a broad mandate, we scale the preference parameters so that their sum equals 2 under both mandates. Thus, if the relative weight on real exchange rate stability is one fifth the relative weight on inflation stability, then under a broad mandate $\mu=0.9090$ and $\delta=0.1818$. 
Table 3: The Performance of Alternative Inflation Targeting (IT) Strategies for Larger Demand Shock Variances $\left(\sigma^{2}{ }_{i}=4\right)$.

\begin{tabular}{|c|c|c|c|c|}
\hline & $\begin{array}{l}\text { REX-IT } \\
\text { Narrow } \\
\mu=1, \delta=0\end{array}$ & $\begin{array}{l}\text { REX-IT } \\
\text { Broad } \\
\mu=0.9090 \\
\delta=0.1818\end{array}$ & $\begin{array}{l}\text { CPI-IT } \\
\text { Narrow } \\
\mu=1, \delta=0\end{array}$ & $\begin{array}{l}\text { CPI-IT } \\
\text { Broad } \\
\mu=0.9090 \\
\delta=0.1818\end{array}$ \\
\hline$V(y)$ & 0.04 & 1.12 & 1.88 & 2.58 \\
\hline$V\left(\pi^{R E X}\right)$ & 0.86 & 0.91 & 0.80 & 0.86 \\
\hline$V\left(\pi^{C P I}\right)$ & 8.00 & 2.93 & 1.48 & 1.06 \\
\hline$V(R)$ & 19.99 & 8.01 & 6.39 & 6.04 \\
\hline$V(q)$ & 22.90 & 7.39 & 6.72 & 3.46 \\
\hline Loss & 0.91 & 3.19 & 3.37 & 3.94 \\
\hline
\end{tabular}

